\title{
Lymphohistiocytic Variant Anaplastic Large Cell Lymphoma
}

National Cancer Institute

\section{Source}

National Cancer Institute. Lymphohistiocytic Variant Anaplastic Large Cell Lymphoma.

NCl Thesaurus. Code C7207.

A histologic variant of anaplastic large cell lymphoma characterized by the presence of a large number of histiocytes admixed with the anaplastic lymphoma cells. 